\title{
SHUTDOWN AND POST-TEST EXAMINATION \\ PLAN FOR THE \\ SMALL STEAM GENERATOR MODEL (SSGM)
}

by
J. W. York

C. E. Sessions

December 1975

ERDA Contract E(04-3)-962
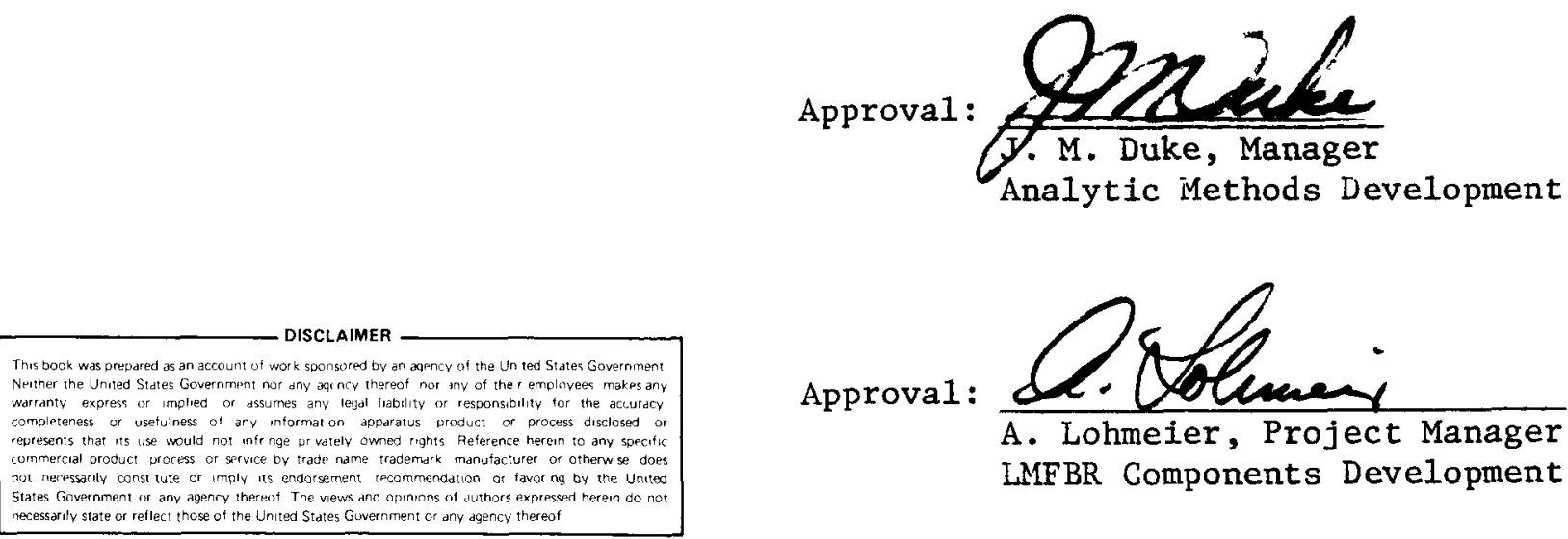

A. Lohmeier, Project Manager LMFBR Components Development

\author{
Westinghouse Electric Corporation \\ Tampa Division \\ P.O. Box 19218 \\ Tampa, Florida 33686
}




\section{DISCLAIMER}

This report was prepared as an account of work sponsored by an agency of the United States Government. Neither the United States Government nor any agency Thereof, nor any of their employees, makes any warranty, express or implied, or assumes any legal liability or responsibility for the accuracy, completeness, or usefulness of any information, apparatus, product, or process disclosed, or represents that its use would not infringe privately owned rights. Reference herein to any specific commercial product, process, or service by trade name, trademark, manufacturer, or otherwise does not necessarily constitute or imply its endorsement, recommendation, or favoring by the United States Government or any agency thereof. The views and opinions of authors expressed herein do not necessarily state or reflect those of the United States Government or any agency thereof. 


\section{DISCLAIMER}

Portions of this document may be illegible in electronic image products. Images are produced from the best available original document. 
A detailed working plan to terminate and to examine the Westinghouse duplex tube small steam generator model (SSGM) is defined and presented. Following completion of the current phase (DNB Corrosion Testing in Off-Normal Water Chemistry) of testing, the Advanced Reactors Division GPL-1/SWL-1 Loops will be shut down on both the water side and the sodium side. The SSGM will be cleaned prior to removal of the model from the test silo. During disassembly and following removal of the model to a dissection area at ARD, visual and photographic records of the SSGM will be made. Secondary cleaning and initial dissection into seven sections will be conducted with protective oils and plastic bags used to inert the outer shell and duplex tube samples.

The major sampling and detailed microscopic examination of the duplex tubing, tube-to-tubesheet welds and tube-support pads will be made following shipment of the dissected model to Tampa. A 72-inch section containing the region over which the "DNB interface" moved during the SSGM testing will be inerted and shipped to General Electric Company for their examination. 
TABLE OF CONTENTS

Section

Title

Page

ABSTRACT .................... i

1.0 INTRODUCTION ................. 1-1

2.0 OUTLINE OF SHUTDOWN AND CLEANING PROCEDURES...$\cdot$ - $2-1$

3.0 PLAN FOR POST TEST EXAMINATION OF SSGM . . . . . . 3-1

4.0 REFERENCES .................. 4-1

APPENDIX I - SSGM Test Procedure, WARD-0I-5164 . . A-1

APPENDIX II - SW-1 Norma1 Shutdown Procedure and Emergency Shutdown, WARD-0I-5163 .......... A-7

APPENDIX III- $\frac{\text { SSGM Shutdown and Cleaning }}{\text { Procedure, WARD-0I-5286 . . . . . A-11 }}$

APPENDIX IV - Procedure For Post-Test Removal of SSGM From the Test Silo, WARD-OI-5292 ........ A-20

APPENDIX V - Outline of Post Test Examination of SSGM . . . . . . . . . . A-28 
LIST OF FIGURES

Figure

1

2

3
Title

Sectioning Diagram for SSGM

Sectioning Diagram for SSGM U-Bend

Partial Sectioning Diagram for the Sodium Inlet End of the SSGM
Page

3-4

$3-6$

$3-7$ 


\subsection{INTRODUCTION}

As part of the ERDA funded Alternate LMFBR Steam Generator Program for Clinch River (CRBRP), the Tampa Division of Westinghouse Electric Corporation designed, $\stackrel{1-3 /}{m}$ manufactured $\frac{4,5 /}{}$ and tested $\frac{6-10 /}{}$ a single duplex tube model of sodium heated steam generator. The unit, named the Small Steam Generator Model (SSGM), was tested in the GPL-1/SWL-1 facility at the Westinghouse Advanced Reactors Division in Waltz Mill, Pa. The duplex tube steam generator design was developed to function as either an evaporator or superheater for the Clinch River Breeder Reactor Plant (CRBRP) under Contract E(04-3)-962. Currently the testing program of the SSGM has been extended to include longer time exposures of the model to off-normal water chemistry conditions. $11 /$

In preparation for the post-test examination of the SSGM, the following document was prepared which describes in detail the GPL-1/SWL-1 1oop shutdown and cleaning procedures, and the current post-test examination plan for the tested SSGM. 


\subsection{ARD LOOP SHUTDOWN AND CLEANING}

Following completion of a three-phase SSGM model test program which has

been defined previous $1 y, \frac{6-10 /}{6}$ the SSGM and ARD test facility GPL-1/SWL-1 will be shut down and cleaned according to the following scheme outlined below prior to the dissection of the model as discussed in Section 3.0. Supporting documentation of this section is given in Appendices I through IV. Basically the procedures are of two types: (1) shutdown and/or (2) cleaning.

\subsection{Sodum Side/Water Side Shutdown}

1. The GPL-1 and sodium side of the SSGM will be shut down and drained in accordance with Revision 3 of ARD Procedure No. 5164 which is given in Appendix I. All trace heaters will then be turned off.

2. The SWL-1 and water side of the SSGM will be shut down in accordance with Revision 0 of ARD Procedure No. 5163 given in Appendix II.

3. Following water side shutdown, the water will be drained per the following actions (reported in ARD Document No. 5286, Revision 3, Appendix III).

- Reduce the water pressure to 0 psig.

- Connect an argon purged line (argon pressure a $\sim 5$ psig) to the Swagelok fitting located in the SSGM's water outlet line.

- With the argon pressure e 5 psig, drain the system. 
- When the system is drained, maintain an argon purge through the system until all breached piping and/or drain valves have been closed. Maintain an argon pressure of 5 psig on the closed system.

\subsection{Cleaning of the SSGM}

1. Following step 3 in Section 2.1, the SSGM will be cleaned in place in accordance with Revision 3 of ARD Procedure 5286 given in Appendix III.

2. Following cleaning, the SSGM will be removed from the silo in accordance with Revision 0 of ARD Procedure No. 5292 given in Appendix IV. After removal, the SSGM will be transported to the disassembly area.

3. The plan for dissection of the SSGM is presented in Section 3.0. 


\subsection{PLAN FOR POST TEST EXAMINATION OF SSGM}

Since the initial purpose of testing a duplex tube steam generator model was to "prove feasibility" of the concept for the Clinch River Breeder Reactor Plant (CRBRP), the post-test examination of the SSGM should accomplish

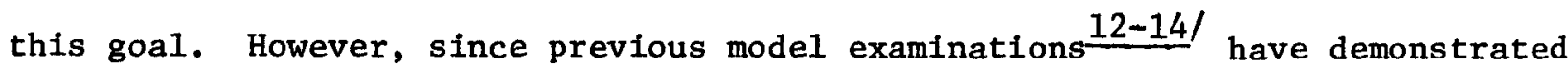
general compatability of $2-1 / 4 \mathrm{Cr}-1$ Mo steel, sodium, and water and since the testing objectives have been expanded to include the behavior under DNB corrosion-fatigue conditions, the plan for the post-test examination of the SSGM has evolved from that defined previously. $15 /$ A detailed plan for dissection of the SSGM that is intended to accomplish the current WTD/GE/RRD objectives for which the SSGM was tested is presented below. A brief outline of this plan is presented as Appendix $V$ for future reference. The detailed plan below includes 16 major items of interest in the examination.

\subsection{Overa11 Performance}

Since cyclic operation could affect the performance of the duplex tube, an initial assessment of any possible structural degradation will be made by reviewing the thermal-hydraulic performance at the end of the three phase test program. Performance at $100 \%$ of design power will be compared throughout the SSGM operation.

\subsection{Visual Observation of External Surfaces}

After completion of the model test program, visual and photographic examination will be performed during removal and disassembly of the model. The first observation, if possible, will view the outside of the exposed duplex tubing through the sodium nozzles to assess sodium wetting and residual sodium on the tube. 


\subsection{Post-Test Cleaning and Preliminary Disassemb1y}

The residual sodium will be removed by the alcohol cleaning procedure given in Appendix III. Only the sodium side should be cleaned with alcohol. These areas will be purged with dry nitrogen and remain under the nitrogen atmosphere as long as feasible. The Sodium Components Technology Group (SCT) will then perform the initial disassembly to remove the insulation, thermocouples, etc. and deliver the model to the lay-down area. During these procedure, the SSGM will be examined to locate any areas which show evidence of damage. Any suspect area will be documented by ARD and WTD personnel.

\subsection{Initial Dissection}

The SSGM with its shell exposed will be re-examined and photographed in the lay-down area. It will also be marked at specific sites before cutting to Indicate the location and orientation of the pieces after the initial dissection. Transverse cuts will be made initially at the seven locations indicated in Figure 1. The eight pieces will include the inlet and outlet assemblies (A\&H), three 12 to $14-1 / 2 \mathrm{ft}$. sections from the long leg (B,C\&D), one $14-1 / 2 \mathrm{ft}$. section from the short $1 \mathrm{eg}(G)$ and two $U$-bend sections approximately 2-2/3 ft. in 1ength (E\&F). Each U-bend section will include approximately a four-inch length of straight tube. Before cutting the U-bend, three bolts will be inserted through the shell adjacent to the $90^{\circ}$ location to support the duplex tube during sectioning. The six duplex tubing sections and the two end assemblies will be pressurized with argon after sectioning and capped.

The shell will be removed from each of the four straight leg sections by lifting the duplex tube and the stay rod assembly out of the shell while the straight section is held in vertical orientation. If this cannot be accomplished because of bowing, the shell will be removed with a milling machine. 
The stay rod assemblies will be separated from the straight duplex tube sections by slitting the support collars with a milling machine. Clamps will be used to minimize vibration at the wear surfaces during cutting.

It should be possible to remove the shell from the U-bend sections without difficulty. The support rods at the $90^{\circ}$ location will be removed and the support bolts loosened. The U-bend sections will then be slipped out of the shell. Throughout the initial dissection and subsequent cutting operations each piece will be identified with respect to location and orientation in the SSGM.

\subsection{Secondary Dissection of the Straight Leg Sections, B,C,D\&G} After inspection and identification marking, the straight leg sections will be recut transversa11y into lengths approximately $3 \mathrm{ft}$. long with certain exceptions as indicated in Figure 1. Transverse metallorgraphy samples will be cut from the remaining tube lengths at the locations indicated in Figure 1. Depending upon the results of the gap measurements, microstructure and evidence of corrosion additional transverse metallographic samples may be examined. Some of the outer tubes of the remaining straight length sections will then be removed by slitting with a miling machine, exposing the outside surface of the inner tube and the inner surface of two halves of the outer tube. Some of the tubes will be sectioned with a vertical band saw. No lubricant or coolant will be used throughout these operations. 


\section{NOTES :}

1. The 72 " long GE sample represents DNE

2. The area $258^{\prime \prime}$ below $\mathrm{Na}$ tubesheet (hot where maximum movement is predicted $t$ inner and outer tubes of the duplex $t$

3. The area $375^{\prime \prime}$ below $\mathrm{Na}$ tubesheet repr where the tendency for the gap betwee to enlarge (at operating temperature) contract from the point to the $\mathrm{Na}$ out

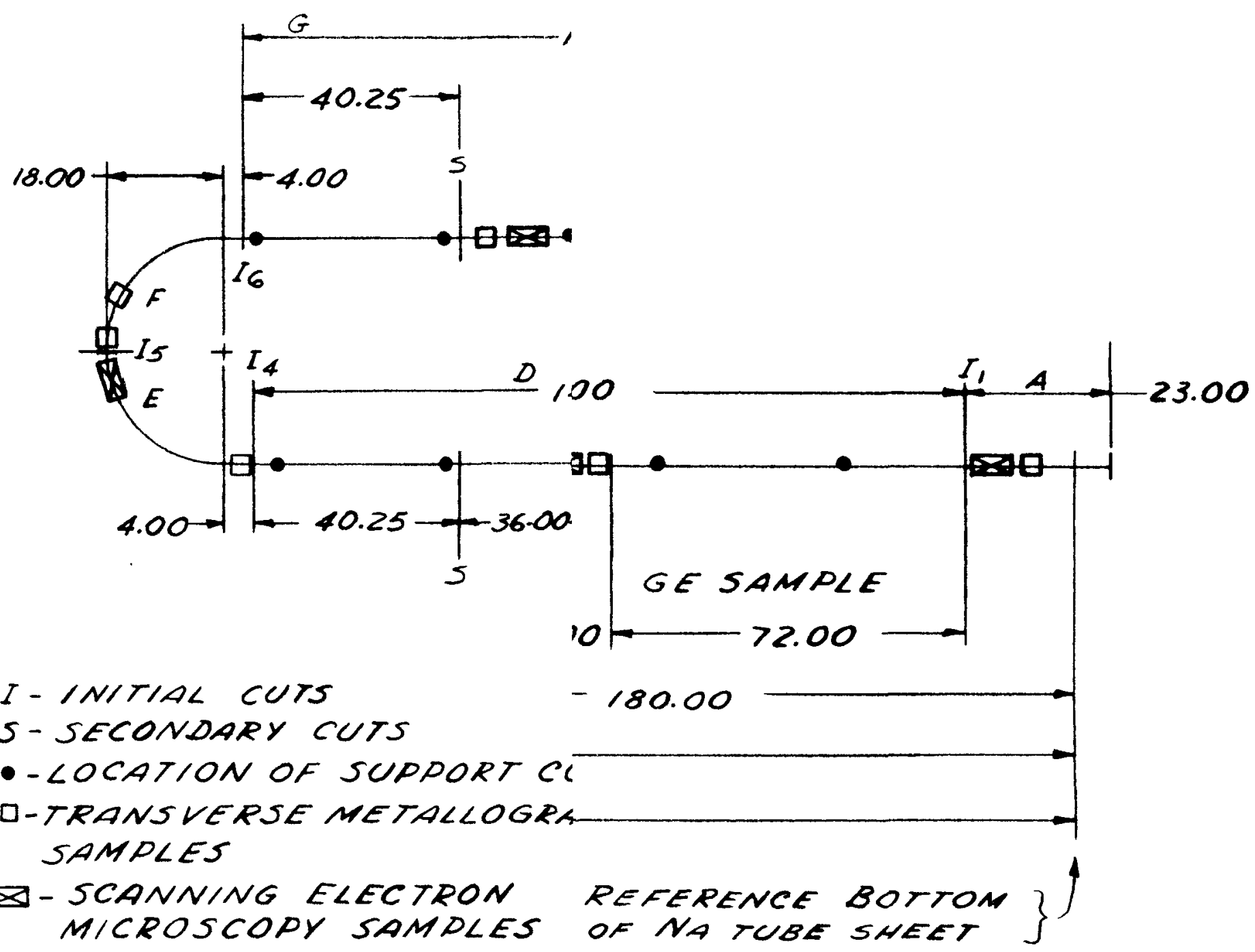

FIG. 1 SECTIONING 


\subsection{Secondary Dissection of the U-Bend Sections, E\&F}

After inspection and identification marking, the two U-bend sections will be cut transversely as indicated in Figure 2 . The cuts may be made with a milling machine and/or a slitting saw. The two metallography samples will be approximately $\frac{1}{2}$ inch 1ong. Depending upon the results of the metallographic and scanning electron microscopy results, additional samples may be taken.

\subsection{Secondary Sectloning of the Inlet and Outlet Assemblies, A\&B} For the purpose of evaluating the tube to tubesheet welds and the duplex tube at the terminus of the outer tube, the inlet and outlet assemblies can be sectioned using the same procedure. The sequential steps in the procedure are listed below.

a) Make the transverse cuts 1,2, 3 and 4 (No. 4 through the she11 only) as indicated in Figure 3 (dissect sodium outlet assembly first).

b) Dye penetrant test and photograph the exposed surface of each weld.

c) Remove excess tube section prior to longitudinal cut which follows.

d) Section the double tubesheet assembly longitudinally, (cut 5).

e) Mount the top half for metallography. The top half is designated as the $0^{\circ}-180^{\circ}$ piece.

f) Resection the $0^{\circ}-180^{\circ}$ piece at the $90^{\circ}$ location to give two quarters with the outer tube held in place with respect to the inner tube. 


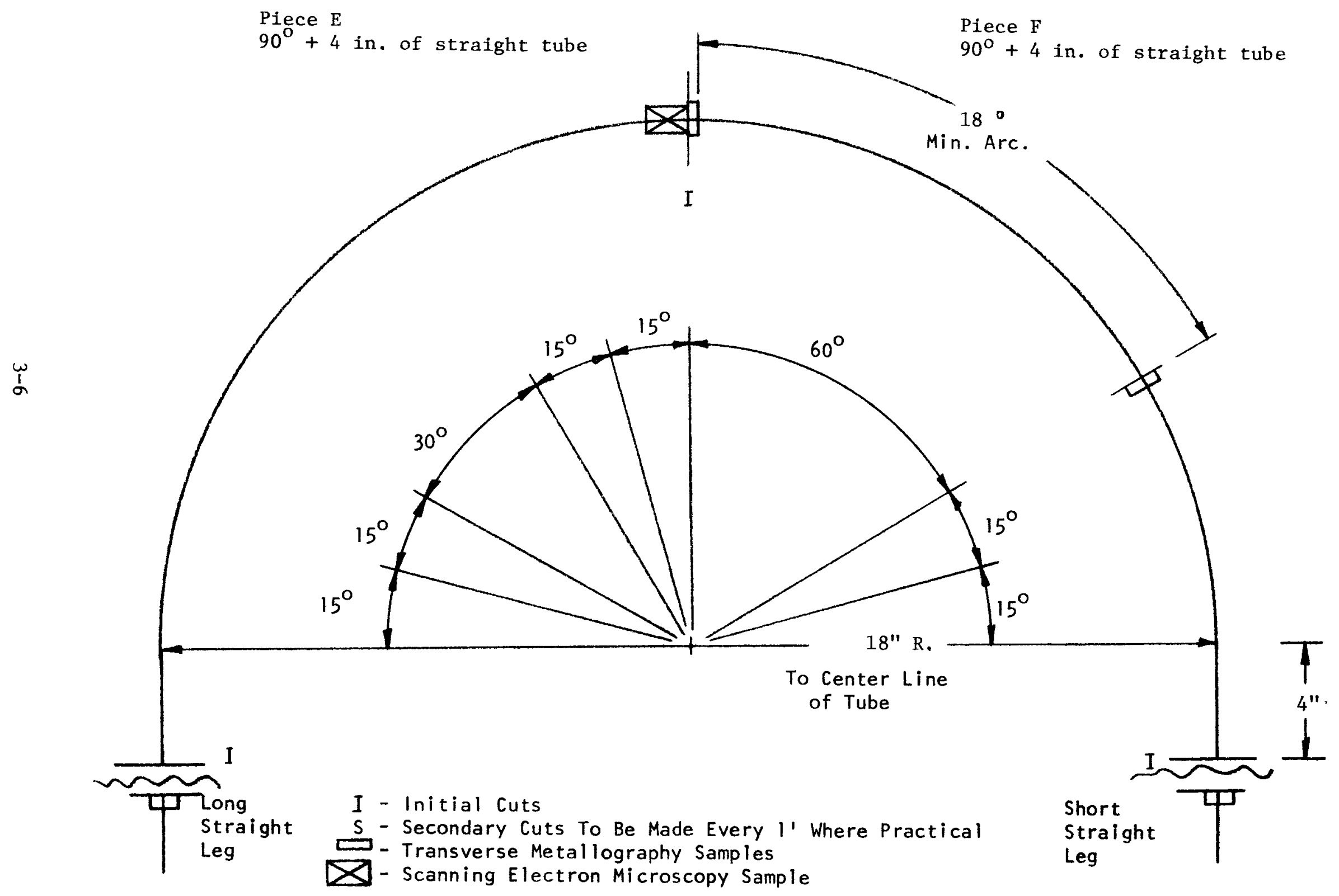

FIG. 2 SECTIONING DIAGRAM FOR SSGM U-BEND 


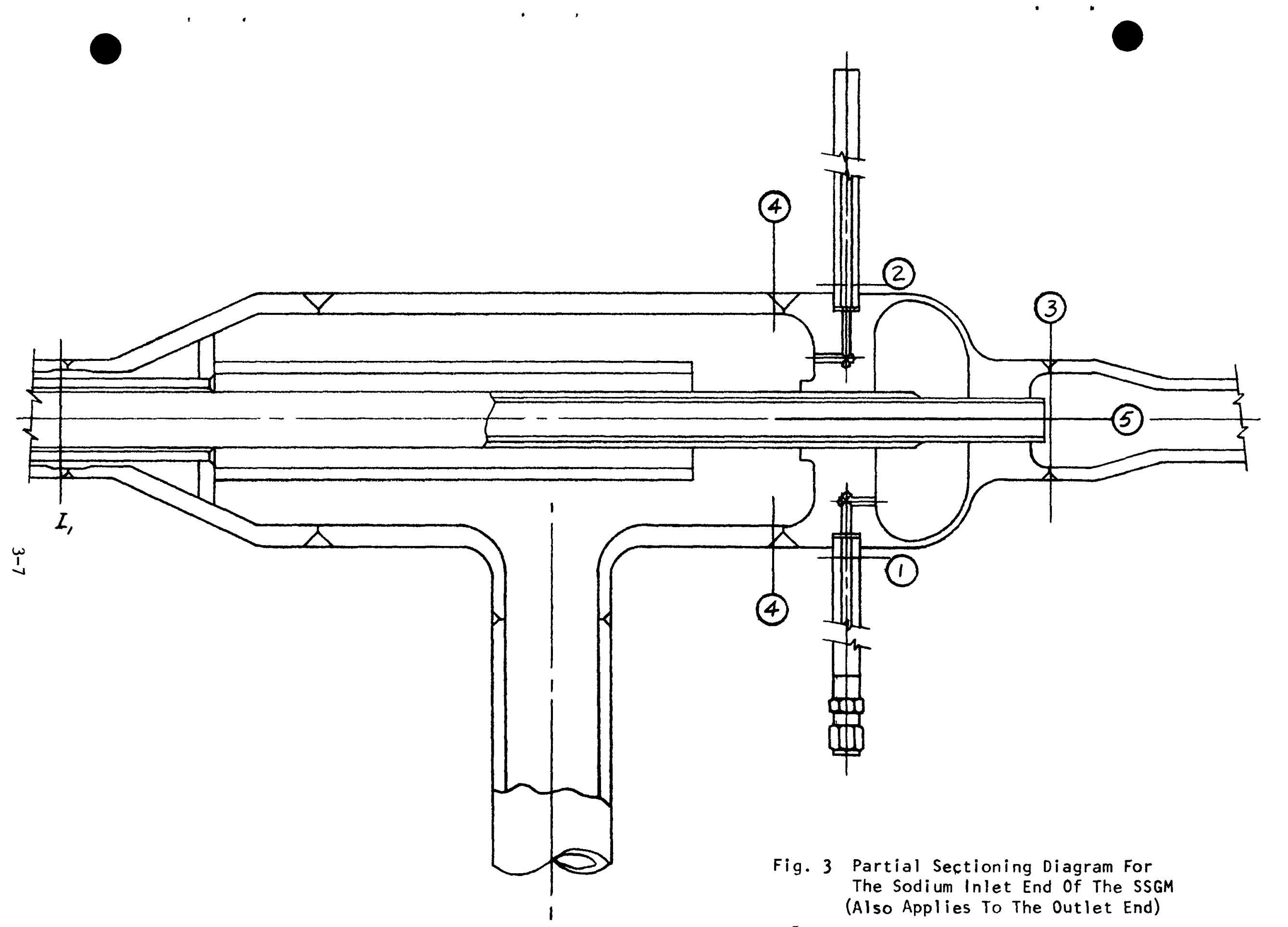


g) Cut the quarters transversely and trim to give longitudinal cross sections through each weld and the outer tube terminus at the $0^{\circ}$ and the $90^{\circ}$ locations.

h) Cut the $180^{\circ}-360^{\circ}$ half of the assembly transversely in the third fluid chamber beyond the outer tube terminus.

1) Lift out the inner tube to expose the interface surfaces of the duplex tube over the length from the sodium tubesheet weld to the transverse cut.

j) Inspect and document both interface surfaces. Retain the free piece of the inner tube for scanning electron microscopy.

k) Recut the weld zones longitudinally at the $270^{\circ}$ location, trim and mount to give longitudinal cross sections through each weld at the $180^{\circ}$ and the $270^{\circ}$ locations.

The following is a list of the samples from the inlet and outlet assemblies each.

Longitudinal Cross Sections at both Sodium and Water Tubesheet:

$$
\begin{aligned}
& 0^{\circ} \text { location with tubes in place. } \\
& 90^{\circ} \text { location with tubes in place. } \\
& 180^{\circ} \text { location with inner tube removed. } \\
& 270^{\circ} \text { location with inner tube removed. }
\end{aligned}
$$

\section{Interface Surface Samples:}

Piece of inner tube $\left(180^{\circ}-360^{\circ}\right)$ over the length from the sodium tubesheet weld to the transverse cut beyond the outer tube terminus. Plece of the outer tube $\left(180^{\circ}-360^{\circ}\right)$ about one half as long as the mating inner tube. Includes the terminus location. 


\subsection{Surface Examination at the Sodium Interface}

After the SSGM sheath has been removed and before the duplex tube has been parted at the interface or the welds sectioned, visual inspection w111 be performed at $1 x$ to $70 x$ magnification and supplemented by dye penetrant testing in the following regions.

1. The sodium and water containment surfaces of both tube-totubesheet welds from each end of the assembly.

2. The entire sodium interface surface of the $U$-bend.

3. The sodium interface surface at the tube supports in the straight legs.

In addition to the general evaluation, selected areas based on location, function and inspection results will be characterized by photography, light microscopy and measurements. Significant areas will be Identified for further evaluation.

\subsection{Dimensional Measurements}

Accurate measurements will be made of the $3 \mathrm{ft}$. nominal length sections from the straight legs and the two $2-2 / 3 \mathrm{ft}$. sections from the U-bend prior to separating the inner and outer tubes. The measurements to be made at the end of each specimen are:

1. Outer diameter

2. Inner diameter

The interface gap plus the size and shape of the grooves will be measured from transverse metallography samples including at least.

1. Six locations from the long straight leg.

2. Two locations from the short straight leg.

3. Two locations from the U-bend. 


\subsection{Duplex Tube Interface Evaluation}

Any deleterious effect of operation on the duplex tube should be evident in changes at the interface long before the effect is reflected in operation. Therefore, the emphasis of the post test examination will be to identify the possibility of potential problems related to long term operation. The examinations described in the following sections will be performed on the duplex tube interface surfaces after the outer tube has been longitudinally parted from the inner tube.

\subsection{Visual Examination of Interface}

With the exception of the short lengths used for transverse sections and for scanning electron microscopy, the entire duplex tube interface will be examined at $1 \times$ to $70 \times$ magnification. The observations will look for indications of wear, galling and self-welding. Areas with significant indications will be documented photographically. These areas will be systematically sampled and examined further by light and scanning electron microscopy to determine the nature and the extent of the effects found.

\subsection{Dye Penetrant Test}

Relative tube motion could result in the creation of tears and/or cracks on the interface surfaces which may not be detected by low magnification visual observation. As these effects would be expected to occur on both the inside of the outer tube and the outside of the inner tube, one of the surfaces will be subject to dye penetrant testing if the surface is found suitable.

The assessment of any indications found will be based 
on tests of unexposed tubing. Significant indications will be further investigated by light and scanning electron microscopy.

\subsection{Profilometer}

Relative motion between the inner and outer tubes could cause changes in the surfaces at the Interface. Circumferential profilometry will be used to evaluate the interface surface of the inner tube using equipment and procedures similar to those described in Reference 2 . Areas evaluated will be selected by location in the model and by preliminary microscopic examination. The results will be used to assess the wear, if any, in the model and select areas for detalled examination by scanning electron microscopy.

\subsection{Scanning Electron Microscopy}

The scanning electron microscopy is the most sensitive equipment for studying the topography of the tube surfaces at the interface. On the other hand the area which can be examined in a reasonable time is 1imited. For example, the maximum specimen size for this study will be a semicircular section of the Inner tube which is two inches long.

Due to the large surface area to be investigated, the SEM will be used for regions identified in the previous examinations which require higher resolution for evaluation. If no areas are identified, then the possible areas of interest include the following.

1. The region where structural analysis predicts that relative tube motion is most likely to occur.

2. The approximate location where the interface gap is predicated to increase due to the radial temperature gradient. 
3. The tube in the region of the sodium inlet.

4. The intersection of the straight legs and the U-bend (approximate point of tangency).

5. A region in the U-bend.

6. A region in the short 1 eg.

7. A region from the long leg.

\subsection{Basis of Evaluation of Interface Effects}

These examinations will look for indications of metal transfer between the tubes (indicating possible self-welding) and the creation of tears and cracks or micro-fissure. The evaluation will be based on the comparison with the examination of the similar tubing without exposure to determine if the indications are a result of the operation of the model, and if a potential problem is indicated. Reports of work performed at $\operatorname{WTD}^{(4)}$ and WARD ${ }^{(15)}$ upon unexposed tubing w111 supply the basic comparison information.

\subsection{Tube-to-Tubesheet Welds}

Besides the duplex tube the post test will examine the tube-to-tubesheet welds of the SSGM. In addition to the visual examination and dye penetrant tests of the outer surface of the weld joint, the weld will be sectioned for metallurgical examination. The focal point of the examination will be the determination of the formation and propagation of any discontinuity at the root of the fillet welds. 


\subsection{REFERENCES}

1. G. Bieberbach, R. P. Waszink, "Liquid Metal Fast Breeder Reactor (LMFBR) Smal1 Duplex Tube Steam Generator - Part I - Design and Thermal Analysis," WNET-104-1 (December 1973).

2. J. C. Dougherty, P. J. Langford and E. W. Pianka, "Liquid Metal Fast Breeder Reactor (LMFBR) Smal1 Duplex Tube Steam Generator Model (SSGM) Part II - Structural Analysis," WNET 104-2 (December 1973).

3. J. Y. Hwang, R. P. Waszink, and L. E. Efferding, "Experimental Evaluation of Thermal Performance - $\underline{W}$ Reference Duplex Tube Samples (Bench Test of Parametric Interface Conditions)," WNET-109 (June 1974).

4. C. E. Sessions, D. G. Harman and W. H. Kinde11, "Manufacture and Inspection Feasibility of Grooved Duplex 2-1/4 Cr-1 Mo Tubing for LMFBR Steam Generator Application," WNET-105 (February 1974) (also paper for presentation ANS Transactions 18, 1:401 (1974) p.117).

5. A. Lohmeier and D. J. Bongaards, "Development and Test Results of Westinghouse Double Wall Tube Steam Generator Including Thermal Model Test, Proceedings of US/USSR SEminar on the Development of Sodium Cooled Fast Breeder Reactor Steam Generators - Volume 1 - Papers, Los Angeles, California (December 2-4, 1974) pp. 221-242.

6. R. P. Waszink, J. Y. Hwang and L. E. Efferding, "Thermal/Hydraulic Performance Test Results of Sodium-Heated Steam Generator Model Employing a Duplex Tube." ASME Paper 75-HT-65 presented at the AIChE - ASME Heat Transfer Conference, San Francisco, California, August 11-13, 1975.

7. R. P. Waszink, J. Y. Hwang and L. E. Efferding, "Therma1 Performance and Critical Heat Flux Test Results of a Sodium Heated Steam Generator Evaporator Model Employing a Duplex Tube (Phase 1 - Parametric Steady State Heat Transfer Experiment), Westinghouse Electric Corporation, Tampa Division, WNET-117 (June 1975). 
8. R. P. Waszink and J. M. Duke, "Transient Test Results of a Sodium Heated Steam Generator Evaporator Model Empllying a Duplex Tube (Phase II Tests)," Westinghouse Electric Corporation, Tampa Division, WNET-118 (August 1975).

9. L. E. Efferding, J. Y. Hwang and R. P. Waszink, "Experimental Evaluation of Critical Heat Flux and Film Boiling Behavior in a Sodium-Heated Duplex Tube Steam Generator Mode1," AIChE Paper No, 996, AIChE Annual Meeting 1975.

10. R. P. Waszink, J. Y. Hwang and L. E. Efferding, "Interim Report Evaluation of Exposure Conditions for the Water-Side Corrosion Test of a Sodium Heated Steam Generator Evaporator Model Empllying a Duplex Tube (2160 Hours at Critical Heat Flux - Phase III SSGM Tests)," Westinghouse Electric Corporation, Tampa Division, WNET-123 (December 1975).

11. W-GE-T10-74-073, "Proposal for Accelerated DNB Corrosion Testing Utilizing Currently Operating SSGM," A. Lohmeier - WTD to R. J. Michalak - GE (November 19, 1974).

12. D. W. Koch and P. J. Kovach, "Materials Examination of a Model Sodium Heated Steam Generator," Babcock and Wilcox Research Center Report No. 5136, BAW-1280-37 (June 30, 1966).

13. J. P. Page, W. H. Friske, T. D. Williams, "Post-Test Examination of Sodium Heated Modular Steam Generator," ASME Paper 74-PWR-18 for presentation at the IEEE - ASME Joint Power Generator Conference Miami Beach, Florida, September 15-19, 1974.

14. J. S. Armijo and G. J. Licina, "Cleaning, Disassembly and Inspection of Sodium Heated Steam Generator Models," ASME Paper 75-PWR-15 for presentation at the IEEE - ASME Joint Power Generator Conference Miami Beach, Florida, September 15-19, 1974. 
15. T. R. Padden, "Procedures for the Post Test Examination and Evaluation of the Duplex Tubing in the SSGM," Attachment to W-GE-T10-74-061, July 19, 1974.

16. W-GE-T10-75-013 Letter from A. Lohmeier WTD to R. J. Michalak, GE including "Pretest Inspection of SSGM," July 17, 1975. 
APPENDIX I

SSGM TEST PROCEDURE 
WESTINGHOUSE ELECTRIC CORPORATION

ADVANCED REACTORS DIVISION

OPERATION INSTRUCTION NO. 5164

\section{SSGM TEST PROCEDURE}

Revision No. $\frac{3}{3-2-74}$
Date Issued $\frac{3-10-74}{2}$
Revision Date

$A-1$ 
EXCERPTS FROM ARD PROCEDURE NO. 5164

\subsection{SCOPE}

This procedure describes the detailed steps required to: 1) fill SWL-1/SSGM and GPL-1/SSGM; 2) start flow thru SSGM; 3) perform shakedown and calibration on SWL-1/SSGM/GPL-1 system; 4) bring the system up to test conditions; 5) perform the test as requested by WTD and 6) shut down and secure the facility.

The revised test request, WTD LM-74-001 (Rev. 1) with supplement \#W-GE-T10-74-030 has revised the scope of testing to include only the following:

Shakedown of GPL-1/SWL-1/SSGM

(Section 5.0 thru $\mathbf{5 . 8}$ of this document)

Calibration of Sodium Flow Meter

(Section 5.9 of this document)

Experimental Determination of Nominal Loads, DNL-2, and DNL-3 Section 6 as per tables 6-2,6-3, and 6-5 as per this document. No transient tesiing will be performed, therefore omit Section 7. The sections, are being left in this document, because the potential exist that the entire test plan may be reinstated. 


\subsection{PURPOSE}

This document ensures that every step in performing the test on SSGM will be performed in a safe and approved manner by qualified personnel to meet the requirements of WTD-LM-74-001 (Rev. 1). This document will delineate the steps to be followed to perform this test in accordance with ARD approved procedures, and constraints imposed upon this facility by the SEC.

\subsection{Implementation}

These procedures must be used by all loop operating personnel. Operating personnel will also be responsible for knowing the applicable provisions of safety and emergency procedures as well as other referenced documents of Section 3.0.

These procedures must be reviewed and updated as required; and no changes will be made without revising this document.

\subsection{Responsibilities}

\subsubsection{Sodium Components Technology Engirieer}

The SCT engineer assigned the responsibility of SWL-1/GPL-1/ SSGM operation is responsible for the following:

1. Preparation of operating procedures for loop operations.

2. Design and installation of all facilities and equipment concerned with loop operation.

3. Providing technical direction for training of operating personnel in the operational and safety aspects of these procedures.

4. Monitor all operations as required to insure that test loop operation is in compliance with these procedures.

5. Reviewing procedures, revising as required and obtaining manager's approval for revisions.

\subsubsection{Sodium Components Technology Technicians}

2.2.2.1 Perform all loop operations in compliance with these procedures by:

1. Having knowledge of all procedural and safety aspects of this document and all referenced documents. 


\subsection{GPL-1/SSGM Na-Side Normal Shutdown}

5.5.1 Decrease the sodium temperature to $400^{\circ} \mathrm{F}$.

5.5.2 Open the GPL-l dump tank/expansion tank equalization valve $(V-22)$.

5.5.3 Set the SSGM dump tank cover gas pressure equal to the SSGM expansion tank cover gas pressure, then open the SSGM equalization valve SPV-102.

5.5.4 Reduce the GPL-1 pump power to a Kw (o amps) and turn off the pump's cooling air blower.

\subsubsection{Close GPL-1 valves 62 and 63.}

5.5.6 Open SSGM drain alves SPV-99,-200,-208 and 209. Also open SSGM valves SPV-201,-202. After opening the SSGM drain valves, open the GPL-1 drain valves 3 and 100.

NOTE: Verify that both systems are draining, as indicated by a decrease in sodium level in the respective expansion tanks.

If either system is not draining, contact the cognizant engineer.

5.5.7 Open GPL-1 valves $4,5,8,9,10,11,12,13,15,32$ and 33 . Do not open valves 32 and 33 if a sodium sample has been isolated.

5.5.8 After draining the system for 30 minutes, reduce the GPL-1 heater/cooler air temperature to $200^{\circ} \mathrm{F}$, then turn off the heater/cooler. Also close the main gas valve and turn off the excess air blower.

5.5.9 Put Swagelok caps on the GPL-1 and SSGM drain tank vent lines.

5.5.10 Put all recorders in the Standby position. If a recorder has no Standby selector switch, turn off the recorder power.

5.5.11 Turn off all loop blowers.

5.5.12 Set SSGM and Silo heaters to $400^{\circ} \mathrm{F}$.

For GPL-1, carry-out procedures per 0.I. 5137. Set SSGM and Silo piping as per heater sheets in Appendix I. This must be done unless explicitly instructed otherwise by the congnizant engineer. 
5.5.13 Put GPL-1 in the Scram condition, then put all GPL-1/SSGM $\mathrm{Na}$-Side valves in the position indicated by the valve position light.

5.5.14 Set the GPL-1 and SSGM argon cover gas pressure regulators at 30 psig.

\subsection{SSGM Water Side Fill}

5.6.1 Be sure all model heaters are off and silo pipe heaters 113,114 and 119 are off. Model temp must be $100^{\circ} \mathrm{F}$ or less.

5.6.2 Follow 015155 and fill SWL-1 as per 5162 .

5.6.3 Reduce SWL-1 pressure to 200 psig or less.

5.6.4 Close V-35 and SPV -37 and open V-36.

5.6.5 Check and be sure SPV-37 is operating.

5.6.6 Open SPV-33.

5.6.7 Slowly bring loop and model to 400 psig.

5.6.8 Open V-76 and vent air from model. (This is only required if the model has been dumped.) Close V- 76 .

5.6.9 Bring the loop and model back up to 4 pro psig.

5.6.10 Open SPV-34.

5.6.11 Bring the loop up to 1000 psig. Vent all high point vents and all DP cell and pressure gages.

5.6.12 Bring loop up to 1260 psig. Adjust Accumulator to $1260 \mathrm{psig}$ as per OI 5162.

5.6.13 Bring loop and model to 1800 psig. Vent and zero all DP cells including model.

5.6.14 Reduce loop and model to 1600 psig.

5.6.15 Adjust pump to 4000 \#/hr. (pump RPM).

5.6.16 Open loop bypass and adjust model flow to $3000 \# / \mathrm{hr}$. with pump at $4000 \# / \mathrm{hr}$., and $1000 \# / \mathrm{hr}$. in bypass.

5.6.17 Adjust loop pressure to have a model inlet of $1750 \mathrm{psig.}$

5.6.18 Adjust mighty mite regulator to have a reasonable bleed. Vent mighty mite outlet to drain.

5.6.19 Circulate until no signs of air in mighty mite outlet. Vent all high points, Dp cells and pressure gages every hour. 
2. Insuring that safety requirements of Section 2.3 are met.

3. Wearing proper safety equipment.

4. Complying with the checklist procedure.

2.2.2.2 Fill in the log book during loop operation by:

1. Recording a neat, concise summary of all events during the shift that pertain to the test.

2. Recording primary data points every four hours and after change to operating conditions.

3. Signing the entry at the end of each shift.

4. Stamp each record (rubber stamp provided) and fill out for each phase of testing, and every 4 hours during steady state testing.

2.2.2.3 Inform the SCT engineer of anomalies unsafe conditions or procedural revisions required.

\subsection{Safety Requirements}

\subsubsection{General}

Two persons must be available at all times at the GPL-1 building for either independent operation of SWL-1 or when operated simultaneously with GPL-1.

\subsubsection{Area Access}

No one is permitted to enter the silo when testing is in operation, and when sodium or water is flowing through the model. This condition is indicated by flashing red warning lights on both sides of the silo, and by blocking entrance to silo with rope barriers.

\subsubsection{Emergency Notification}

In the event of an emergency during shift operation as well as during "off hours" the following personnel are to be notified in the order shown:
W. R. Miller
412-837-8139
R. L. Laubham
$412-372-3139$
R. L. Eicher
412-547-8073
C. R. Smith
$412-837-8856$ 
APPENDIX II

SWL-1 NORMAL SHUTDOWN PROCEDURE AND EMERGENCY SHUTDOWN

A-7 


\author{
APPENDIX II \\ WESTINGHOUSE ELECTRIC CORPORATION \\ ADVANCED REACTORS DIVISION
}

OPERATION INSTRUCTION NO. 5163

SWL-1 NORMAL SHUT DOWN PROCEDURE AND EMERGENCY SHUT DOWN

Revision No. $\frac{0}{2-22-74}$
Date Issued
Revision Date


SWL-1 Normal Shutdown and Emergency Shutdown

I. Normal Shutdown

1.0 Reduce feedwater temperature (boiler outlet) to $150^{\circ}$ in $100^{\circ} / \mathrm{hr}$ steps. (Not to exceed $150^{\circ}$ per hour.)

2.0 Put a11 bypass switches in bypass condition.

3.0 Reduce system pressure to 1200 非 by using relief valves.

4.0 After $150^{\circ}$ feedwater is achieved, turn off gas fired boller and close two hand operated gas valves.

5.0 Decrease feedwater pump slowly unt1l low flow alarm is received then stop pump immediately.

6.0 Turn off air blast cooler.

7.0 Turn off chilled water pump, cooling tower blowers and sump pump. Also close blower louvers $D-1, D-2, D-3$ and $D-4$.

8.0 Isolate accumulator by closing valve $\mathrm{V}-1$ and $\mathrm{V}-2$.

9.0 Shut off inlet and outlet of demineralizer.

10.0 Close argon valves to instruments located in back of Console 3 $(\mathrm{V}-73)$.

11.0 Close air supply valve to make up pumps $(\mathrm{V}-74)$.

12.0 Close water supply and water discharge to make up pumps.

13.0 Close water supply valve to cooling tower sump (CV-20).

14.0 Open cooling tower sump drain valve* (CV-22).

15.0 Close supply air for SWL-1 loop (V-29).

16.0 Secure all electrical breakers.

* NOTE: This valve will be opened only if outside temperature is below $40^{\circ}$. 


\section{Emergency Shutdown}

1.0 In the event of a scram initiated shutdown, the SWL-1 1oop will be isolated from the test section. The main feedwater pump, air blast cooler, and boiler will be shut off and loop bypass valve will come to full open.

2.0 Isolate system alarms and switch into bypass conditions.

3.0 Notify Test Engineer immediately.

4.0 Restart main feedwater pump and cool feedwater temperature to $150^{\circ}$.

5.0 Continue with step 2.0 thru 16.0 of normal shutdown procedure. 
APPENDIX III

SSGM SHUTDOWN AND CLEANING PROCEDURE

A-11 
APPENDIX III

WESTINGHOUSE ELECTRIC CORPORATION ADVANCED REACTORS DIVISION

Document No. 5286

SSGM SHUTDOWN AND CLEANING PROCEDURE

Revision No. $\frac{3}{11-11-75}$
Date Issued
Date Revised




\section{$1.0 \quad$ SCOPE}

After the SSGM Phase III Test has been completed, the GPL-1/SSGM/SWL-I System will be shut down. The SSGM will then be cleaned and removed from the test silo. This procedure covers the shutdown and cleaning of SSGM. Removal of SSGM from the test silo will be covered by a separate procedure.

\subsection{PURPOSE}

The purpose of this procedure is to outline the operations which will be used to shut down and clean the SSGM.

\subsection{APPLICABLE DOCUMENTS}
a. ARD Drawing No. 1452F39, "GPL-1/SSGM/SWL-1 System Schematic."
b. ARD Drawing No. 766J576, "GPL-1/SSGM/SWL-1 Piping Installation."
c. Tampa Drawing No. L-LM-1008-3a, "SSGM Design Layout."

\subsection{PROCEDURE}

1. After completing the SSGM Phase III Test, shut down the GPL-1/SSGM/SWL-1 System per instructions outlined in ARD Operating Instruction No. 5164, "SSGM Test Procedure" dated March 16, 1975.

2. Set the GPL-1/SSGM (sodium side) argon cover gas pressure at 5 psig.

3. De-energize the SSGM heaters and, with the exception of the heaters on valves $62,63,99$ and 109, all heaters on the SSGM-side of valves 62 and 63. Note: Set the silo sodium drain tank temperature at $300^{\circ} \mathrm{F}$.

4. Drain the water from the SWL-1/SSGM as soon as possible after termination of testing. The water is to be drained from the system while purging with argon. Purge this system with argon for two hours at $\sim 20$ cfh unti1 the dewpoint of the exit gas and entrance gas are equal (i.e., less than $-40^{\circ} \mathrm{F}$ ). The water side is to be maintained at, or greater than, $200^{\circ} \mathrm{F}$ during this operation. After the purge has ended, the water side system is to be maintained with an argon gas pressure of 5 psig. 


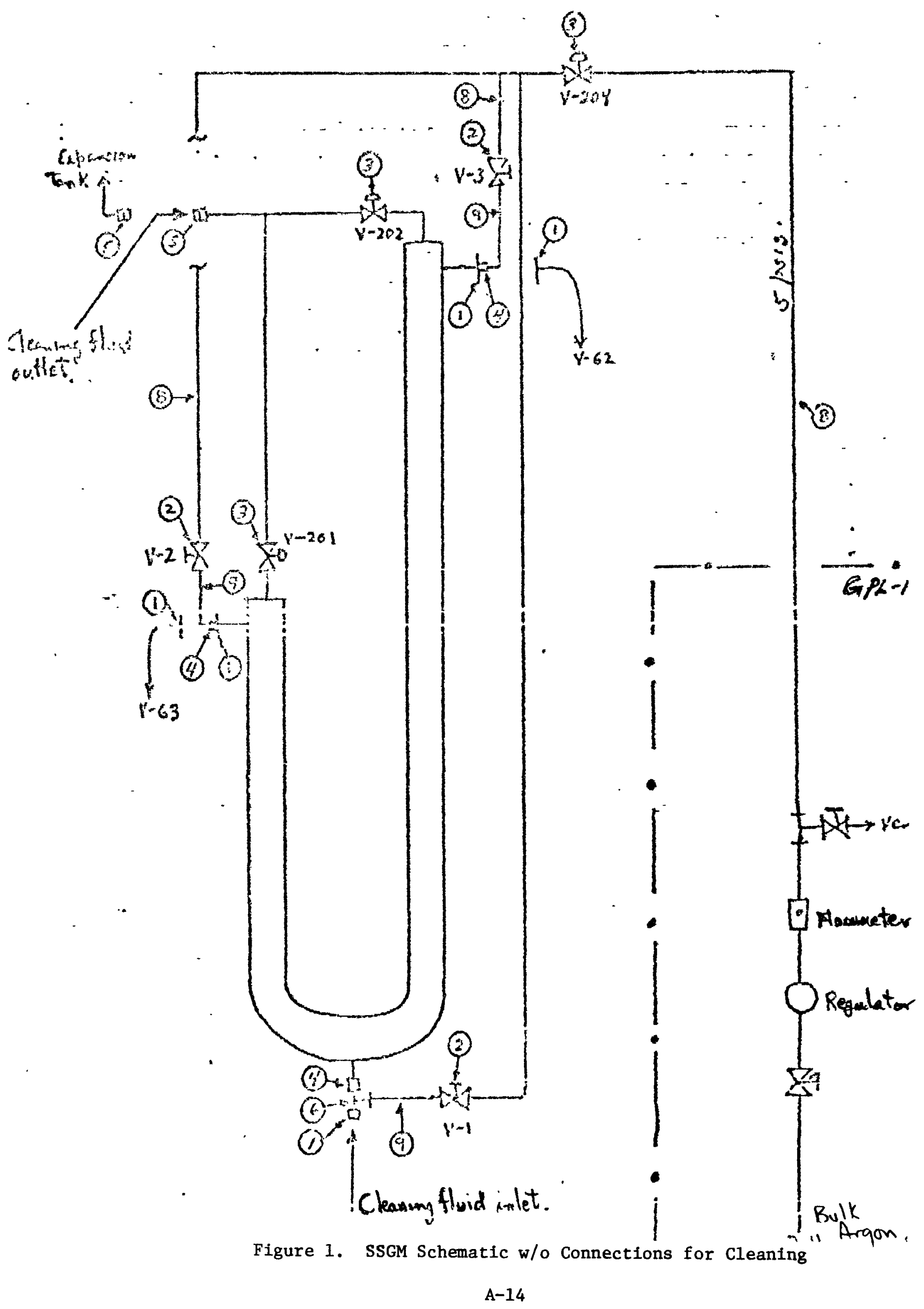




\section{Figure 1 Legend}

1. P1ate Type 304SS, 1/4 inch thick.

2. Valve, Whitey, $1 / 2$ inch SS (Cat. No. 8VS8-316).

3. Existing valves.

4. Swagelok Male Pipe Weld Connector (Cat. No. S5-810-1-8MPW).

5. Swagelok Union W/Swagelok Plug (Cat. No. SS-810-6).

6. Swagelok Union Tee (Cat. No. SS-810-3).

7. Swagelok Plug (Cat. No. SS-810-P).

8. Tubing, $1 / 2$ inch Refrigeration Copper.

9. Tubing, $1 / 2$ inch Type 304 SS. 
5. Replace the SSGM helium supply cylinder with an argon supply line (equipped with regulator and supply valve). Before initiating sodium removal, purge the SSGM Helium System with argon for two hours at $2 \mathrm{cfh}$ to stop the purge and maintain the argon pressure at 5 psig.

6. When the SSGM is at amblent temperature, cut the SSGM sodium inlet and outlet lines 12 inches from the model while purging with argon. Weld plates ( $1 / 4$ inch thick, type $304 \mathrm{SS}$ ) to both ends of the cut piping. The plates on the mode1-side of the piping will be equipped with $1 / 2$ inch Swagelok male pipe weld connectors. Welding while maintaining argon purge w111 follow standard ARD procedures.

Connect argon supply to both Swagelok connectors and set the argon pressure at 5 psig (Figure 1 ).

7. Cut the SSGM sodium drainline $\sim 5$ inches from the model while purging with argon. Weld a $1 / 2$ inch Swagelok male pipe weld connector to the model-side of the piping. Connect a $1 / 2$ inch Swagelok Union Tee to the Swagelok Connector. Install a Swagelok plug on one side of the tee; connect an argon supply line to the other. side and set the argon pressure at 5 psig (Figure 1).

8. Cut the SSGM sodium vent tubing $\sim 24$ inches from the model's expansion tank while purging with argon. Install 1/2 inch Swagelok unions to both ends of the cut tubing. Install 1/2 inch Swagelok plugs on both unions.

9. Clean the SSGM per instructions outlined in Appendix A. 
1. Connect alcohol and argon systems to drained, isolated SSGM as shown schematically in Figure 2 (water side to have been drained and entire SSGM inerted with dry argon during connection).

Reestablish positive argon purge of water side following alcohol drain.

2. Maintain positive internal pressure on water side, helium third fluid side and sodium side during all the following steps.

3. Establish argon flow of TBD $\mathrm{cfm}$ ald TBD psig to sodium side thru V1, $\mathrm{V} 2$ and V3. Verify $\mathrm{O}_{2}$ level in atmosphere vent line to be $<2 \mathrm{v} / \mathrm{o}$ before proceeding. Calibrate gas chromatograph for $\mathrm{H}_{2}$ and determine system background $\mathrm{H}_{2}$ concentration. Verify $\mathrm{TC}$ readings are ambient. Sample and analyze fresh ethanol for specific resistance and water content.

4. Pump ethanol from storage drum into the sodium side of the SSGM at a flow rate of TBD gpm. (FI11 rate and cycling rate will be determined by model's temperature and effluent $\mathrm{H}_{2}$ concentration; control of $\mathrm{fill}$, cycling rate, and of possible emergency draining will be accomplished by adjusting designated valves.) Monitor model temperature, effluent $\mathrm{H}_{2}$ concentration and specific resistance/ $\mathrm{Na}$ ion content of effluent continuously during initial fill and cycling. Control and EOSR (end-of-step requirements) during fill and cycling are to be as follows:
a. Maximum permissible model/alcohol temperature $\leq 145^{\circ} \mathrm{F}$
b. Maximum permissible $\mathrm{H}_{2}$ concentration, effluent $\leq 3.5 \mathrm{v} / \mathrm{o}$
c. EOSR $\mathrm{H}_{2}$ concentration
$\leq 10 \mathrm{ppm}$
d. EOSR model/alcohol temperature
e. $\operatorname{EOSR} \Delta \mathrm{C}^{2 *}$ ambient
$\leq 10 \mathrm{ppm}$

The following optional emergency procedures may be followed if either condition $a$. and/or $b$. of above is reached.

1) Increase argon flow rate (sparge) to maximum permissible rate, considering pressure limits of the system, to cool the model and lower the effluent $\mathrm{H}_{2}$ concentration.

*

Change in sodium concentration in alcohol cycled for any continuous two-hour period, assuming 20 gallons ethanol cycling. 
2) Drain alcohol from system to spare storage drum and increase argon flow. Refill system and begin cycling when ambient temperature and background $\mathrm{H}_{2}$ concentration has been reestablished.

5. Using existing SSGM heaters, increase alcohol temperature while cycling to $140^{\circ} \mathrm{F} \pm 5^{\circ} \mathrm{F}$ maximum at $10^{\circ}-20^{\circ} \mathrm{F} / \mathrm{hr}$ heat-up rate. Continue monitoring of effluent $\mathrm{H}_{2}$ concentration, alcohol/model temperature, Nat concentration and specific resistance. After reaching $140^{\circ} \mathrm{F}$ alcohol temperature, continue cycling with control until the following EOSR are reached:
1) $\operatorname{EOSR~} \mathrm{H}_{2}$ concentration
$\leq 1 \mathrm{ppm}$
2) EOSR model temperature
3) $\mathrm{c}_{\mathrm{na}}^{2 *}$$$
140^{\circ} \mathrm{F} \pm 5^{\circ} \mathrm{F}
$$$$
\leq 10 \mathrm{ppm}
$$

Maximum permissible model/alcohol temperatures, maximum permissible affluent $\mathrm{H}_{2}$ concentration, and optional emergency procedures during this step will be described in Step 4 above.

6. Cool SSGM and drain alcohol to storage drum. Sample alcohol for final $\mathrm{Na}+$ concentration. Maintain argon purge of SSGM during this step.

7. Using fresh ethanol, fill SSGM as in Step 4 above. Cycle alcohol and increase alcohol temperature to $140^{\circ} \mathrm{F} \pm 5^{\circ} \mathrm{F}$ as in step 5 above.

8. Repeat Steps 6 and 7 as necessary until the following EOSR are reached.
1) $\operatorname{EOSR~H} \mathrm{H}_{2}$ concentration
None detected
2) $\operatorname{EOSR~C} 2$
$\leq 1 \mathrm{ppm}$
3) Optical density
$\leq 3$ Jackson Units

9. After final ethanol cycle, drain ethanol into storage drum and sample for final $\mathrm{Nat}$ concentration analysis. With model temperature at $140^{\circ} \mathrm{F} \pm 5^{\circ} \mathrm{F}$, purge with argon until no ethanol can be detected in the effluent argon. 


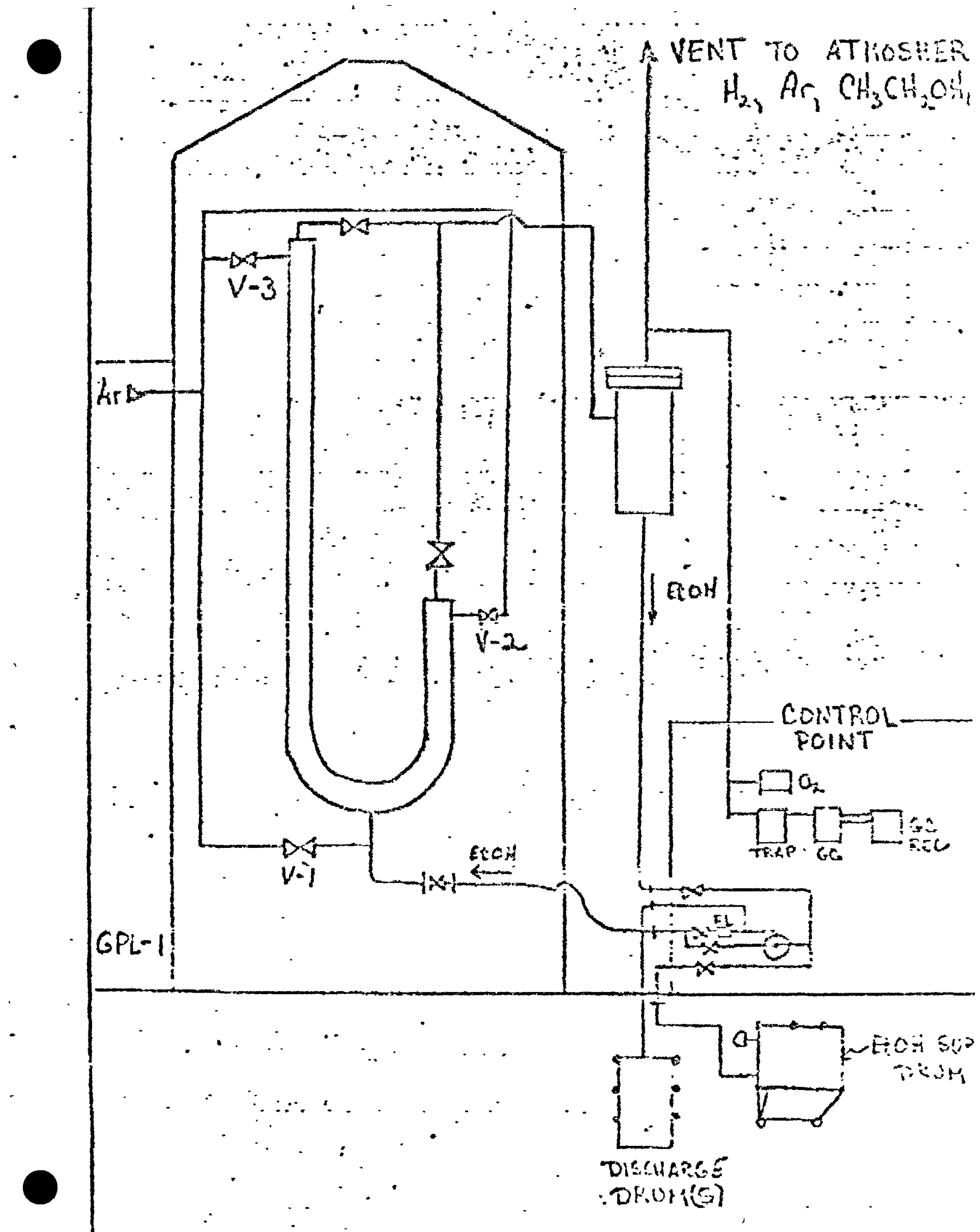

Figure 2. Schematic Showing Connections for Alcohol and Argon Systems 
APPENDIX IV

PROCEDURE FOR POST-TEST REMOVAL

OF SSGM FROM THE TEST SILO

A-20 


\section{APPENDIX IV}

\section{WESTINGHOUSE ELECTRIC CORPORATION ADVANCED REACTORS DIVISION}

Document No.

5292

PROCEDURE FOR POST-TEST REMOVAL OF SSGM FROM THE TEST SILO

Revision No. $\frac{0}{\text { Original Issued } 11-19-75}$
Date Revised




\subsection{SCOPE}

This procedure describes the operations associated with removing the SSGM from the test s110 and transporting it to ARD's D-Building, following completion of the SSGM Phase III Test. This procedure is essentially a reversal of the SSGM installation (in the Test Silo) Procedure 5157 (Revision 0 ) and does not cover sectioning and shipment of the SSGM.

\subsection{PURPOSE}

The purpose of this procedure is to outline the steps necessary to safely and properly remove the SSGM from the Test Silo and transport it to ARD's D-Bullding. The operations will be carried out by qualified personnel in accordance with Tampa WNET-104, Section 3 and using RDT F8-6T (Hoisting and Rigging of Critical Components and Related Equipment) as a guide.

\subsection{REFERENCE DOCUMENTS}

The following documents are part of this procedure.

3.1 Tampa document WNET-104 (Section 3)

3.2 ARD IH\&S Safety Procedure No. 1 - Lifting Device Inspection (ARD)

ARD IH\&S Safety Procedure No. 10 - Cranes - Load Testing (PEVARNIK)

ARD IH\&S Safety Procedure No. 11 - Cranes - Inspections (PEVARNIK)

ARD IH\&S Safety Procedure No. 22 - Crane Operators (PEVARNIK)

\subsection{RELATED EQUIPMENT}

4.1 The following equipment are the items to be lifted.

4.1.1 The SSGM (Tampa Dwg. L-LM-10008-3A) mounted on support structure (Tampa Dwg. 1100J28 (wt-3000 1bs.))

4.1.2 Silo roof - On S11o (wt=1000 1bs.)

4.1.3 Silo I-beam - In Ṣilo-(wt= 500 1bs.) 
4.2 The following equipment for lifting and hauling w1ll be supplied by "PREVARNIK Bros. Inc", Latrobe, PA, with qualified operators. 4.2.1 Crane A - $138 \mathrm{ft}$. Ifft 3 ton cap. 4.2.2 Crane B - $60 \mathrm{ft}$. lift 10 ton cap. 4.2.3 Cherry Picker $65 \mathrm{ft}$. 1ift 1-man cap. 4.2.4 $40 \mathrm{ft}$. long flat bed trailer and tractor - 3 ton cap.

4.3 The following ARD inspected and approved slings and lifting equipment w111 be used.

4.3.1 4 leg cable sling - 6 ton cap. \#3-7

4.3.2 2 - $20 \mathrm{ft}$. nylon slings $\$ 301$ and 302

4.3.3 2 - $20 \mathrm{ft}$. cable slings \#299 and 300

4.3.4 2 - $10 \mathrm{ft}$. nylon slings \#282 and 283

4.3.5 $1-1-1 / 2$ shackle cap - 30 tons

4.3.6 8 - 1" shackles cap - 6 tons

4.3.7 2 - $100 \mathrm{ft}$. hand lines (plastic or hemp)

4.3.8 54" I-beam spreader

\subsection{SILO ROOF REMOVAL}

5.1 Park cranes and trailer as shown on Figure 1; when trafler is parked, remove tractor. Be sure traller wheels are chocked.

5.2 Loosen the turn buckle that secures the roof to the silo.

5.3 With the cherry picker parked on the north bank above the silo, maneuver the basket with one man in it to a position that the outside turn buckle can be loosened. This turn buckle is on the west side of the silo.

5.4 Position the basket so that the fiberglass panel in the roof can be removed. Lower the fiberglass panel to the ground using a hand line. 
5.5 Position crane so that the crane boom can lift the roof, and swing the roof over on to the north bank clear of the area.

5.6 Using a $10 \mathrm{ft}$. nylon sling, one man in the cherry picker will attach the crane A hook to the roof lifting ring. Use a 1 " shackle to make this lift.

5.7 Move the cherry picker basket clear of crane and roof movement.

5.8 Remove the s1lo roof and place it on the bank north of the silo.

5.9 Attach a $10 \mathrm{ft}$. nylon sling in choke on the 10" I-beam in the silo. Attach the sling to the hook on Crane A, take the slack out of the sling, but do not put a strain on the beam.

5.10 Remove the I-beam securing bolts on the west end of the I-beam. Remove the I-beam securing bolts on the east end of the silo from the cherry picker. Clear personnel out of silo prior to lift.

5.11 Remove the I-beam and stow it on the north bank behind the silo.

\subsection{SSGM REMOVAL}

6.1 Attach two legs of the four-legged sling to the shackles on the cable spreader. Attach the D-ring on the four-legged sing to the hook on Crane A.

6.2 Lower the cable spreader through the top of the silo until it can be reached by ARD personnel.

6.3 Attach the two 10-ft. nylong slings to the lifting rings on the upper support channel of SSGM using two 1-1nch shackles. Attach the free end of these slings to two 1-inch shackles on the cable spreader.

6.4 Remove the slack from the aforementloned slings, then, while maintaining tension in the slings, remove the twelve, $1 / 2-20 \mathrm{x}$ 1-1/2 inch long bolts which secure SSGM to the silo support structure. NOTE: The SSGM support structure/silo support structure tack welds already will have been broken. 
6.5 Slowly lift the SSGM until the bottom of the SSGM is near the top of the silo, then attach a hand line to the lower end of the SSGM support structure.

6.6 Slowly lift the SSGM until it can be moved beyond the silo, then lower the SSGM unt11 the bottom of the SSGM is $\sim 20 \mathrm{ft}$. above the ground. During this operation use the hand line to avoid swinging the SSGM.

6.7 Attach the two, 20-ft. cable slings to the lifting rings on the U-bend end of SSGM support structure, using 1-inch shackles. Attach the free end of these slings to the hook on Crane $B$, using a 1-1/2-inch shackle.

6.8 Slowly lower Crane A and simultaneously raise Crane B until the SSGM is horizonal and 20-ft. above ground. During this operation do not permit the hook-on Crane B to touch the SSGM thermocouples.

6.9 Move the SSGM, in the horizonal position, until it is above the traller, then slowly lower and position the SSGM on the trailer.

6.10 Remove all crane slings from the SSGM and secure the SSGM support structure to the trailer with 1-ton load binders.

6.11 Connect the tractor to the traller and very slowly transport the SSGM into D-Building.

6.12 Re-Install the silo roof (see Section 7.0).

6.13 In D-Building, attach the two 20-ft. cable slings to the lifting rings on the U-bend end of the SSGM, using 1-inch shackles. Also attach two 20-ft cable slings to the lifting rings on the tubesheet end of the SSGM. Attach the free end of these slings to the hook on the D-Building crane, using a 1-1/2-inch shackle.

6.14 Raise the SSGM until it "clears" the trailer. Remove the trailer from D-Bullding and lower the SSGM to the wooden skids on the floor of D-Bullding. 
NOTE: The sodium and water-sides of the SSGM will be maintained under an argon pressure of 5 psig until it is cut into sections per instructions from $W$ Tampa and/or G.E.

\subsection{SILO ROOF RE-INSTALLATION}

7.1 Using $10 \mathrm{ft}$. nylon sling, in choke lift I-beam with Crane A.

7.2 Position I-beam in silo to align with holes in brackets and bolt in place.

7.3 Remove crane hook and sling from I-beam.

7.4 Attach the $10 \mathrm{ft}$. nylon sling to the lifting ring on the roof with a 1" shackle.

7.5 Lift roof over silo, align with silo, and lower into place.

7.6 Secure the outside roof turn buckle from the cherry plcker.

7.7 Secure the inside roof turn buckle from the inside of the structure extension.

7.8 With one man in the cherry picker, install the fiberglass panel on the silo roof.

\subsection{DOCUMENTATION AND INSTRUCTIONS}

8.1 The author of this document is designated "Person In Charge" (PIC).

8.2 The PIC will witness all steps in this operation.

8.3 The PIC will familiarize all persons performing this task with this procedure and instruct said persons to carry out all steps.

8.4 All lifts made in this procedure will be documented with photographs.

8.5 The PIC will take all necessary steps to minimize the hazards to all workers, particularly ARD personnel, by assuring that al1 applicable safety rules and procedures are employed. 


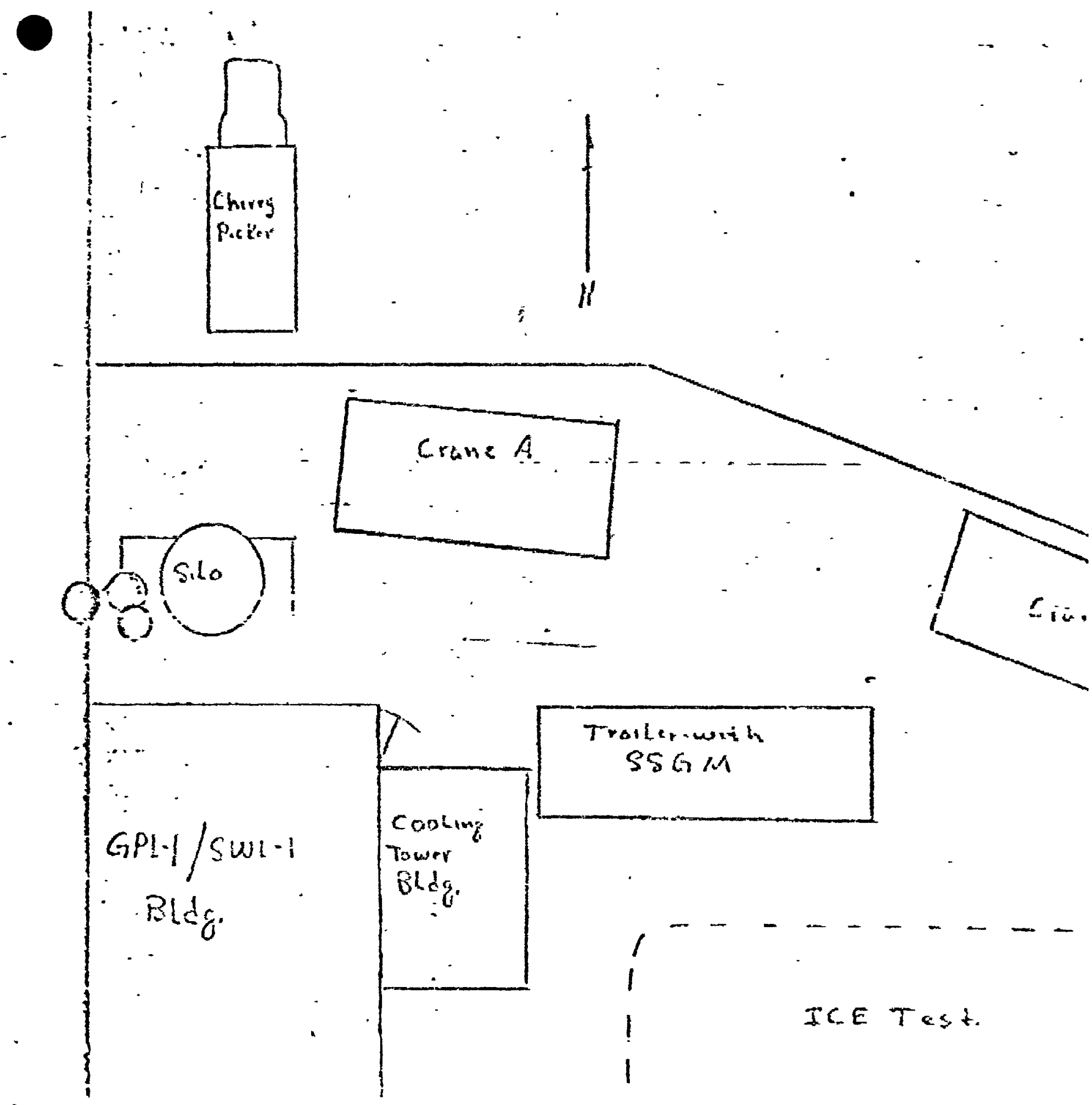

Figure 3. Schematic of Equipment Positions During Planned Removal of SSGM from Test Silo 


\section{APPENDIX V}

\section{OUTLINE OF POST-TEST EXAMINATION \\ OF SSGM}


This appendix is intended as a brief guide of the plan to dissect the SSGM as outlined in detail in Section 3.0 Post-Test Examination (p.2 of WNET-122). This gulde is intended to be used simply as a check-off list in accomplishing the overall objectives of the SSGM post-test examination. The guide is divided into two sections according to the location at which the actual work is to be performed, i.e., either (a) at Westinghouse Advanced Reactors Division or (b) at Westinghouse Tampa Division.

Westinghouse Tampa Division drawings of the SSGM model that are required for use in this dissection plan are listed below:

1100J74 SSGM T/C Instrumentation Heater Arrangement (PL 1100J74A01)

1100J71 SSGM Long Leg Tube Bundle Detailed Assemb1y (PL 1100J71A01)

1100J73 SSGM Final Deta1led Assemb1y (PL 1100J73A01)

$1100 J 72$ SSGM Long Leg "U" Bend Detailed Assembly (PL 1100J72A01)

2501B21 SSGM Tube Support Sleeve (PL 2501B21000)

2647A30 Supplementary Manufacturing Data for SSGM.

3456C60 SSGM Long and Short Leg Deta1led Assemb1y

(PL 56C60A01 and PL 56C60A02)

3456C57 SSGM Tube Schedule

3456C52 SSGM Shroud Support P1ate (PL 56C52000)

3456C50 SSGM Sodium Tube Sheet (PL 3456C50000)

3456C49 SSGM Steam Tube Sheet 


\section{A. Dissection and Examination at WARD}

After completion of the model test program, visual and photographic examination will be performed during removal and disassembly of the model. During the removal, any areas of rubbing or areas affected by holding fixtures, bands, etc. should be noted as to position and photographed. The following steps should be taken following removal:

1. Insulation at the inlets and outlets of sodium and steam areas should be photographed and conditions noted.

2. The insulation should be stripped away and the model photographed. Any areas that appear unusual should be documented as to location and photographed.

3. Photograph and inspect stainless steel covering sheath. Should a spot weld inadvertently touch the vessel pipe, mark this are and record the location.

4. ' Scribe locations on pipe (vessel shell) as to its location above the reference point (target of bend area).

5. Measure the location of all thermocouples and should any be loose or not touching the vessel wall, record the number, location and photograph the thermocouple.

6. Photograph and measure location of the heaters.

7. Remove thermocouples and heaters taking care not to damage, and ship to Tampa Division.

8. Remove support channel and discard.

9. * A request was made by Waszink to radiograph a section of (1) the bend area and (q) a section of the long leg (sodium inlet side) in order to determine if duplex tube is near the center of the model. If the model is laying down and the tube and tube supports have too much clearance between them and the vessel wall, this may not be a meaningful check.

* Decision to be made before dissection. 
10. Mark the positions of the Initial seven cuts according to the attached Figure 1. Label each section according to A, B, etc. Scribe angular orientation with relation to a reference mark on Section A (sodium inlet tubesheet area). Scribe two marks in the one location so that a scratch would not confuse an orientation. Scribe only the end towards the sodium inlet and this will maintain that position orientation.

11. Cut shell and duplex tube at initial cut number 1 and, before any other cuts are made, scribe the angular reference mark on the cut interface of both the shell and the duplex tube. Spray the sodium inlet end of each sectioned piece throughout the entire operation with paint (yellow, etc.). This w11l color code the sodium inlet side on each sectioned vessel wall and duplex tubing.

12. Note and photograph the position of the "bird cage" in each instance where access is possible.

13. Complete the other Initial cuts indicated in Figure 1 and photograph.

14. Remove the duplex tubing and supports from the shell by pulling on the duplex tube or etc. Spray OD and ID of shell with WD-40 and prepare for shipment to WTD. (Note special instruction for GE sample, item 8.)

15. Photograph typical and any unusual areas. Determine if any tube-totube support galling occurred. Look for any area where unusual sodium flow has occurred.

16. Mark duplex tubing for secondary cuts. Label each section $B 1$, $\mathrm{B} 2, \mathrm{C} 1, \mathrm{C} 2$, etc. as cuts are made within a given section. The major Sections B, C, etc. are designated as letters on Figure 1 and the numerals are subsections. The subsections should have the lowest number toward the sodium inlet area. Scribe angular marks before secondary cuts are made. Section and spray paint on end nearest sodium inlet. Record length of each duplex tube section.

17. Prior to making cut I5, drill three holes (1/4 in. dia.) and establish location of U-bend tube support. Use three positioning bolts to hold tube steady during subsequent sectioning. Make cut I5 so as not to pass through the U-bend tube support. 
18. The OD and ID of the WTD duplex tubing samples should be sprayed with WD-40 to prevent rusting. The 72 " section "G.E. sample" should have the ID protected by VPI powder only and the OD sprayed with WD-40. Al1 rubber or cork stoppers should be inserted in each of the two ends of each subsection of tubing. Clean cloths sprayed with WD-40 should then be used to wrap these pieces of tubing and then place piece in plastic wrapping and seal. Record identity on outside of the plastic wrapping.

19. Before dissecting section $A$ and $H$ in Figure 1 , care should be taken to locate the dissimilar metal welds. These areas should be marked and identified so that they can be shipped to G.E. after sectioning.

20. Sectioning of the two heads $A$ and $H$ should begin with the less critical lower head (H) which is the sodium outlet of the model. The sectioning should be accomplished as shown in Figure 3. The approximately 1 ' length of tubing (between $I_{1}$ and cut (4) should be removed after PT of the lower weld.

21. On the sodium outlet, remove the vent lines by making cuts (1) and 2 .

22. Make cut (3) in Figure 3 and prepare the top portion containing the dissimilar metal weld for shipment to G.E. Also remove the sodium outlet piping with the dissimilar metal weld (for G.E.).

23. Make cut (4). Note that this cut only penetrates the she11 and does not section the duplex tubing. After this cut is made, the two sections should be separated by pulling in the horizontal direction. Should the tube-to-tube support area not allow the removal of the tube, then the duplex tube may have to be severed above the tube support near $I_{1}$ (Figure 3 ).

24. Dye penetrant inspections of the welds should be performed now and later at WTD. Record and photograph results.

25. Make cut (5) which sections the upper part of the head.

26. Perform a visual examination and photograph any unusual areas. Spray the components with WD-40, wrap in clean WD-40 sprayed rags, etc. 
27. Steps 20 thru 26 should be performed on the upper head (sodium inlet head).

28. * Have the $72 "$ section for G.E. (Figure 1) milled at WARD so that the outer tube can be removed and the surface roughness made and sample immediately shipped to G.E.

29. Obtain copy of shipping paperwork. Make sure that specimens are shipped to WTD care of cognizant engineer.

30. Alert WTD Receiving of the shipment.

B. Dissection and Examination at WTD

After the samples are received at WTD, the following steps are suggested:

1. Arrange for storage in an air-conditioned area.

2. Select the pleces of duplex tubing from which specimens for metallography and scanning electron-microscopy are to be removed (see Figure 1 ).

3. Write instructions to metallurgical laboratory concerning sectioning, marking and preservation of specimens.

4. Assist technician in marking actual location on duplex tubing for the sectioning operation.

5. Technician should record dimension of tubing and exact locations from which specimen taken.

6. Section 6" length of one piece in cold leg and send to G. Gaul (G.E.) for comparison of water side tubing that was not in a DNB region. Record position from which specimen was taken.

7. Vacuum mount transverse metallography specimens in resin either at WTD or University of Florida. Polish and etch according to technique developed at WTD. Record gap measurements and evaluate results to determine if it will be necessary to take additional specimens. If no trend or change is evident in gap measurements, then the number of specimens examined (nine, noted in Figure 1) is sufficient. 
8. Section specimens for scanning electron microscopy examination at University of Florida. A visual and macroscopic examination of the specimens should be performed before examination on the SEM so that any unusual areas may be located. Evaluate results of scanning electron-microscopic examination to determine if there is a need for more specimens.

9. Remove a 6" length of duplex tubing next to the SEM specimens.

10. Mill outer tube off these specimens and make surface roughness measurements. Evaluate results to determine if there is a need for more examination.

11. Based upon results to date of surface roughness, gap measurements and SEM define extent of further sectioning required to assess behavior of the duplex tube model.

12. Perform any additional testing on the duplex tubing that is required by the evaluation performed in step 11 .

13. Sectioning of the tube-to-tubesheet welds is dependent upon the results of the dye penetrant examination (PT). It may be deternined at this time to examine the surface of these weld segments on the scanning electron microscope or go directly to light microscopy. If dye penetrant indications do exist, then a sectioning scheme will be devised for the examination. In many cases, if a crack exists, it is desirable to break a portion of the crack open and examine on the scanning electron microscope to determine the mode of failure or to analyze for corrosion products with the EDAX system (Energy Dispersive Analysis by X-rays). This examination would be followed by light microscopy examination.

14. Evaluate results of work performed in step 13 and combine with results obtained in steps 11 and 12 for the overall evaluation.

15. Store samples and specimens insuring that there is proper protection against corrosion.

16. Write report, review and issue final report of examination of SSGM. 
NOTES :

1. The 72 " long GE sample represents DN

2. The area $258^{\prime \prime}$ below Na tubesheet (ho where maximum movement is predicted inner and outer tubes of the duplex

3. The area $375^{\prime \prime}$ below $\mathrm{Na}$ tubesheet rep where the tendency for the gap betwe to enlarge (at operating temperature contract from the point to the $\mathrm{Na}$ ou

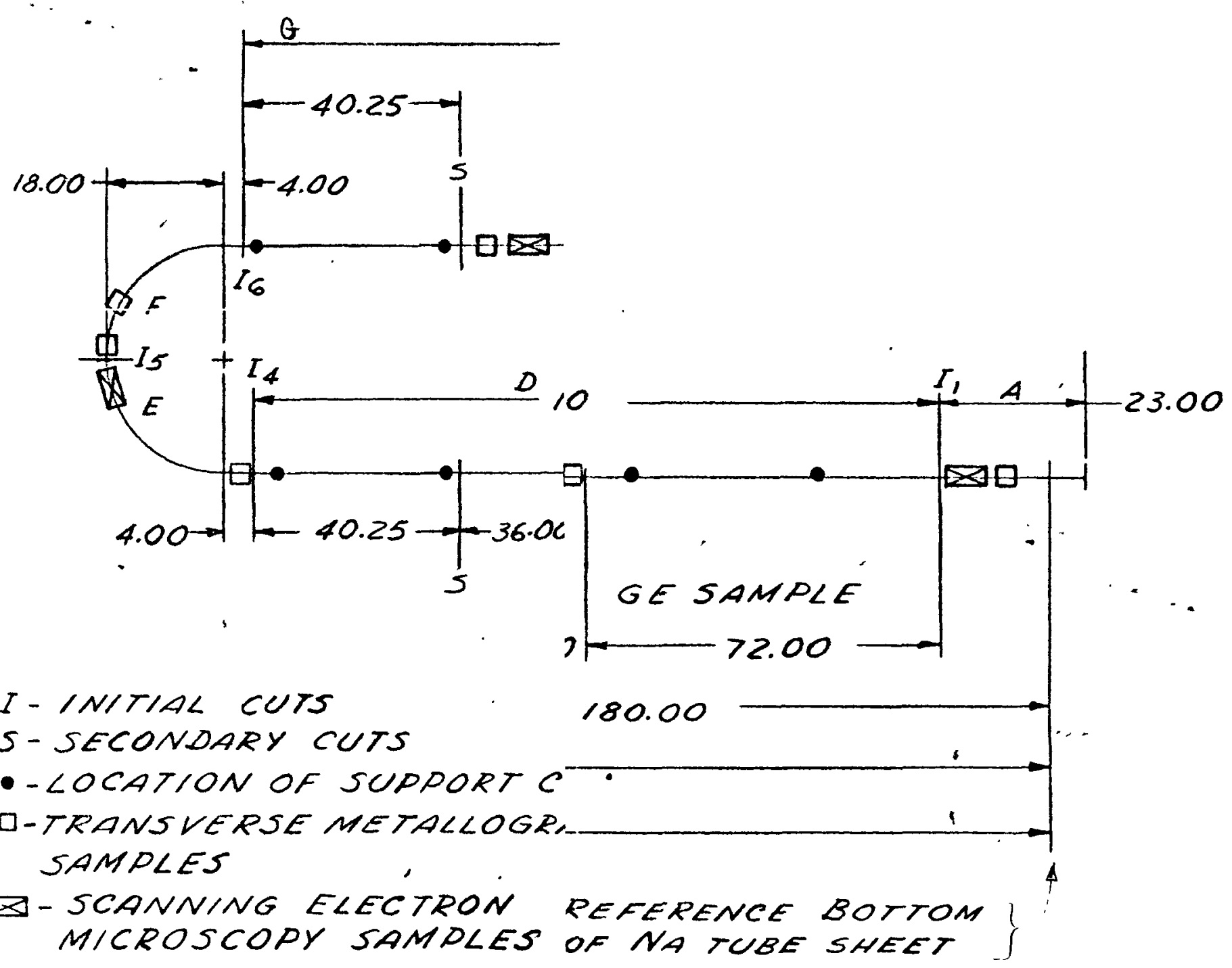

FIG. 1 SECTIONINC 


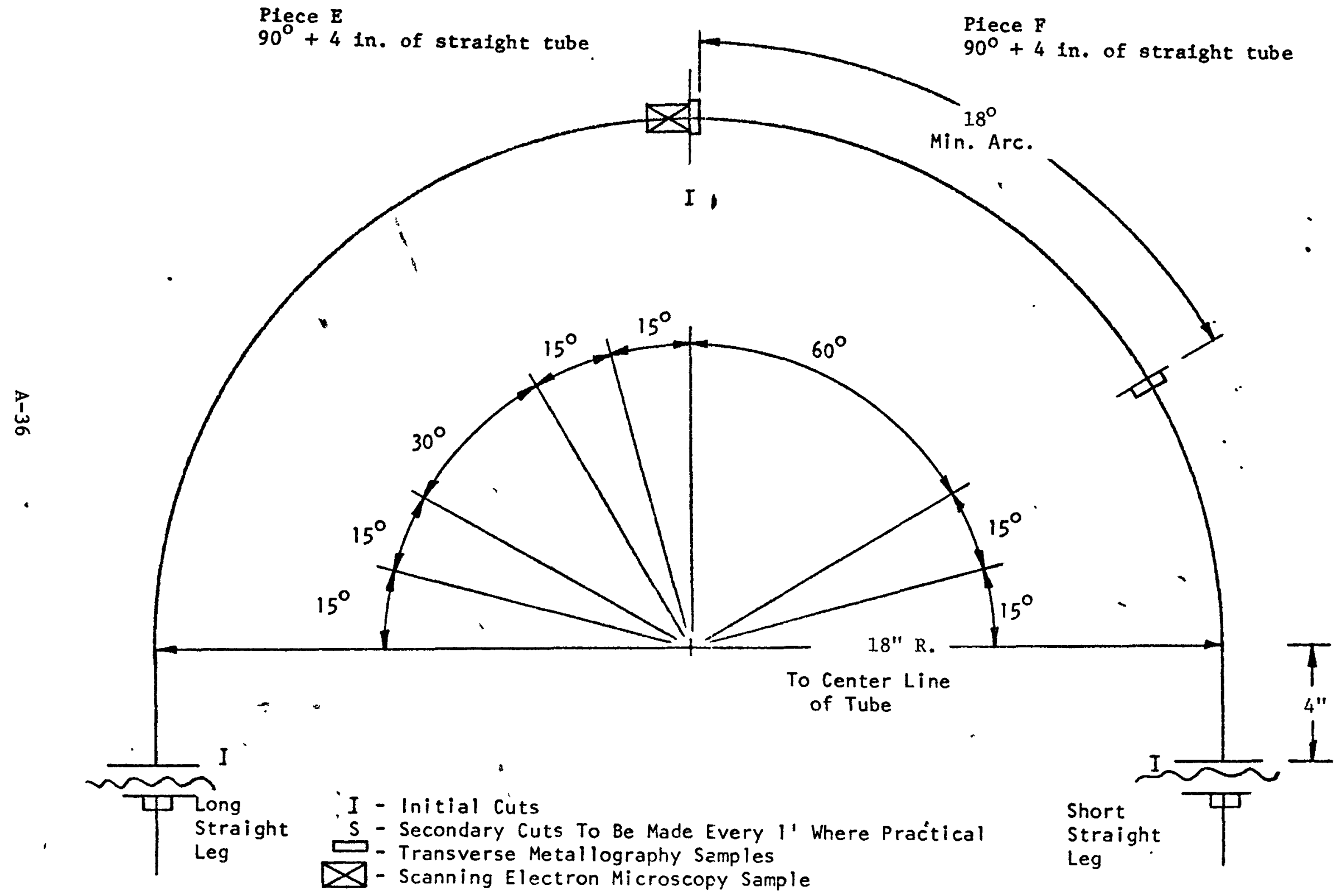

FIG. 2 SECTIONING DIAGRAM FOR SSGM U-BEND 


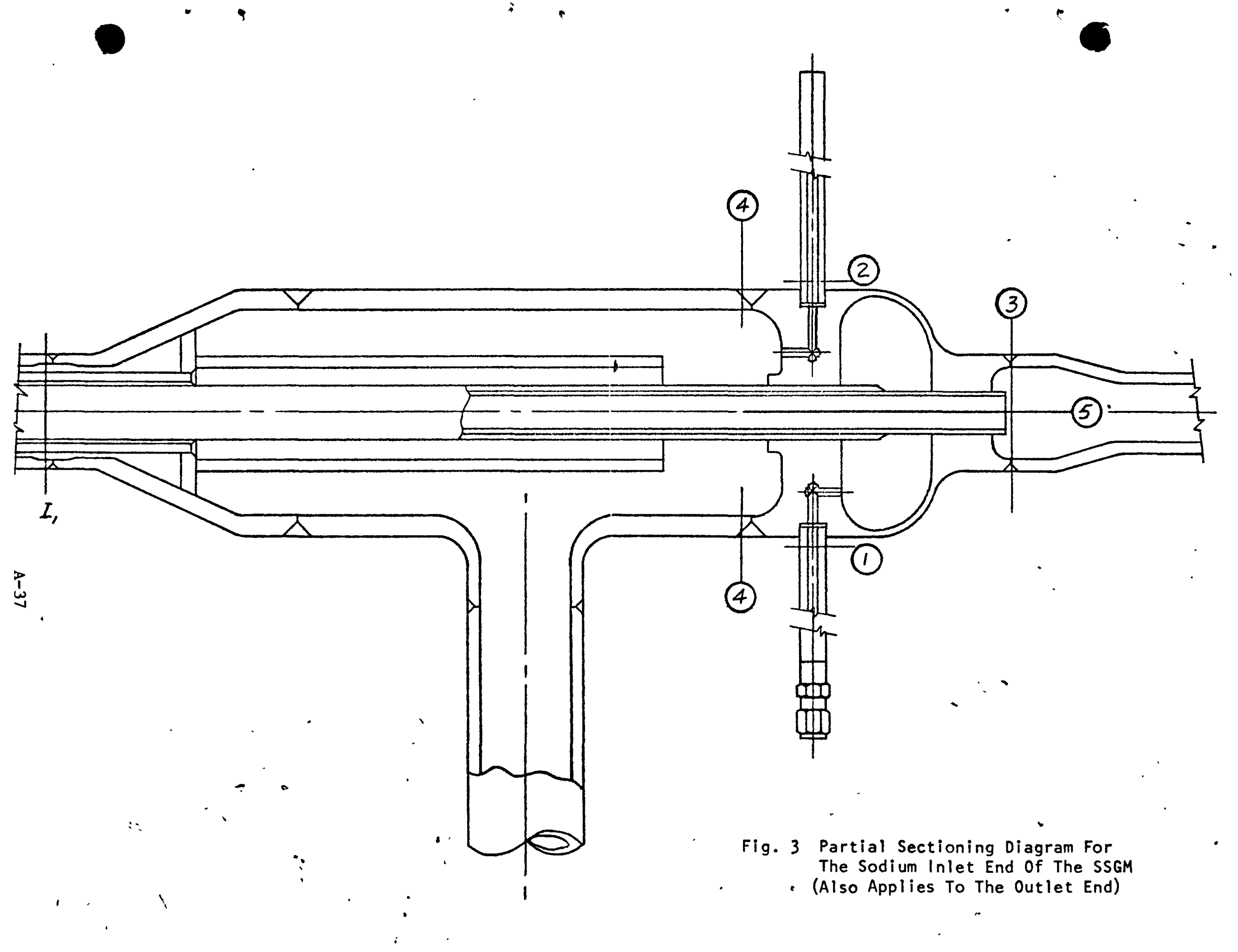

